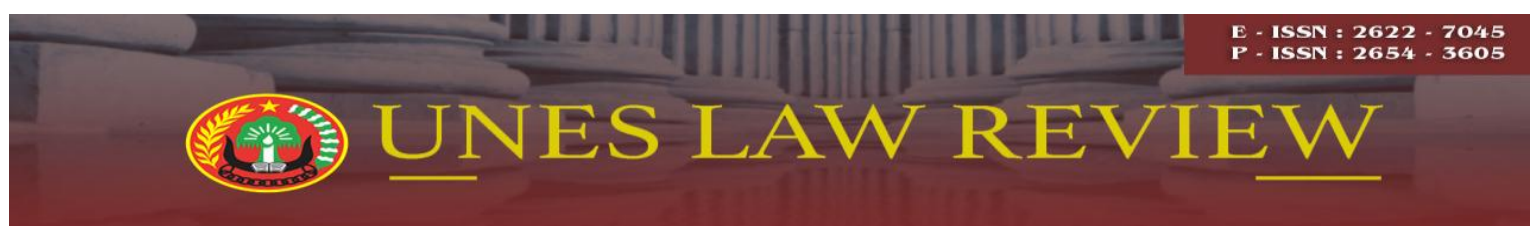

Email: uneslawreview@gmail.com

Online: http://review-unes.com/index.php/law

Volume 2, Issue 4, Juni 2020

\title{
PERTIMBANGAN HAKIM TINGKAT BANDING DALAM MENERAPKAN UNSUR-UNSUR PASAL 2 DAN PASAL 3 UNDANG-UNDANG NOMOR 31 \\ TAHUN 1999 TENTANG PEMBERANTASAN TINDAK PIDANA KORUPSI (Studi Putusan No. 3/TIPIKOR/2016/PT PDG dan No. 9/ TIPIKOR/ 2017/PT PDG)
}

\author{
Rinaldi $^{1}$, Wirna Rosmely ${ }^{2}$ \\ ${ }^{1}$ Program Magister Ilmu Hukum, Universitas Ekasakti, Padang, Indonesia \\ Email: misterrinaldi9@gmail.com \\ ${ }^{2}$ Fakultas Hukum, Universitas Ekasakti, Padang, Indonesia \\ Email: wirnarosmely@ymail.com
}

\begin{abstract}
The law governing criminal acts of corruption is Law Number 31 of 1999 as amended by Law Number 20 of 2001 concerning Eradication of Corruption. Corruption crime regulated by Law Number 31 of 1999 consists of various forms / types. In writing this thesis, the author conducts research on corruption cases as referred to in decision Number 3 / TIPIKOR / 2016 / PT PDG and Number 9 / TIPIKOR / 2017 / PT PDG. From the results of the study, the first conclusion was obtained that the consideration of the appellate level judges in applying the elements of Article 2 and Article 3, that in Decision Number 3 / TIPIKOR / 2016 / PT PDG, was the legal judgment of the First Level Judge in its decision that could be approved and corroborated by the Level Judge Appeals, except in the case of conviction for the Defendant, according to the Judge of the Level of Appeals the imposed criminal sentence needs to be aggravated and there are still incriminating matters for the Defendant that have not been considered by the First Level Judge. Criminal application by the Court of Appeal Court is to improve the decision of the First Level Court which imprisonment for 2 (two) years and 6 (six) months and improvement of imprisonment for 3 (three) years and a fine of Rp 50,000,000 (fifty) million rupiahs) subsidair criminal confinement for 2 (two) months. Judge's consideration in Decision Number 9 / TIPIKOR / 2017 / PT PDG, is that the Panel of Appeal Judges has considered Article 2 with elements of a criminal offense committed by the defendant. The Appellate Court Judges disagree with the decision of the First Level Court regarding the Acts of the Defendants in violation of Article 3 of Law Number 31 of 1999 concerning Eradication of Corruption. Based on the results of the examination of legal facts in the trial and the consideration of the Panel of Appellate Judges with the Primair indictment proved and fulfilled all elements of Article 2 paragraph (1) Juncto Article 18 paragraph (1) letter $b$ paragraph (2) and paragraph (3) of Law Number 31 of 1999. The application of the criminal sentence dropped to Defendants II and IV for 4 years and fined Rp. 200,000,000.00 (two hundred million rupiah).
\end{abstract}

Kata Kunci: Pertimbangan Hakim Tingkat Banding, Pemberantasan, Tindak Pidana Korupsi 


\section{PENDAHULUAN}

Jauh sebelum negara Indonesia terbentuk di tanah air kita, pada masa-masa penjajahan Kolonial Hindia Belanda korupsi telah ada, sampai saat lahirnya negara Indonesia 17 Agustus Tahun 1945 dan sampai pula sekarang bangsa Indonesia telah mengecap kemerdekaan selama 74 tahun. Walaupun negara Indonesia telah merdeka, Indonesia hanya terlepas dari bentuk penjajahan phisik dan masih terbelenggu dari bentuk penjajahan non fisik yang berarti masih terjajah dalam bentuk jajahan baru yaitu kejahatan korupsi. Pelakunya adalah dari bangsa sendiri, digambarkan bagaikan sebuah batang tubuh digerogoti serangan virus korupsi telah menggerogoti negara kita, yang merugikan keuangan negara dan perekonomian negara yang akibatnya mengancam kesejahteraan bangsa serta kemajuan bangsa dan negara. Tindak pidana korupsi menjadi salah satu masalah yang paling menonjol di Indonesia, korupsi yang terjadi di Indonesia saat ini, sudah dalam posisi yang sangat parah dan begitu mengakar dalam setiap sendi kehidupan.

Dalam hal penelitian ini penulis ingin mengetahui lebih dalam terhadap isi putusan tingkat banding Nomor 3/TIPIKOR/2016/PT PDG dan Nomor 9/TIPIKOR/2017/PT PDG sehingga akan menambah pengetahuan dan pemahaman terhadap suatu putusan. Dalam perkara tindak pidana korupsi Nomor 39/Pid.Sus/ TPK/2015/PN Pdg., yang diajukan permintaan banding oleh Terdakwa dan Penuntut Umum perkara mana terdaftar Nomor 3/TIPIKOR/2016/PT PDG dimana salah satu pertimbangan hukumnya pengadilan tingkat banding menyatakan bahwa Pengadilan Tingkat Banding sependapat dengan pertimbangan hukum Pengadilan tingkat pertama dengan mengambil alih pertimbangan tersebut dijadikan sebagai pertimbangan sendiri dalam mengadili perkara di tingkat banding, namun dalam penjatuhan pidana terhadap Terdakwa pengadilan tingkat banding tidak sependapat dengan pertimbangan pengadilan tingkat pertama tersebut dan perlu diperbaiki dengan memperhatikan hal-hal yang memberatkan bagi Terdakwa yang belum dipertimbangkan oleh pengadilan tingkat pertama.

Dalam perkara tindak pidana korupsi Nomor 9/TIPIKOR/2016/PT PDG., dimana Hakim Tingkat Pertama dalam putusanya menyatakan para Terdakwa terbukti secara sah dan meyakinkan bersalah melakukan Tindak Pidana Korupsi secara bersama-sama sebagaimana dakwaan Subsidair sebagaimana diatur dalam Pasal 3, berbeda dengan pertimbangan Hakim Tingkat banding yang menyatakan semua unsur yang terkandung 
dalam Pasal 2 ayat (1) Undang-undang Nomor 31 Tahun 1999 Tentang Pemberantasan Tindak Pidana Korupsi sebagaimana telah diubah dan ditambah dengan Undang-undang Nomor 20 Tahun 2001 terbukti perbuatan Terdakwa. Pertimbangan Hakim Tingkat Banding dalam perkara ini membatalkan putusan Pengadilan Tingkat Pertama.

Berdasarkan latar belakang di atas, maka permasalahan yang diangkat dalam penelitian ini adalah :

1. Bagaimanakah Pertimbangan Hakim Pengadilan Tingkat Banding Dalam Menerapkan Unsur-Unsur Pasal 2 dan 3 pada putusan Nomor 3/ TIPIKOR/2016/PT PDG dan Nomor 9/TIPIKOR/2017/PT PDG?

2. Bagaimanakah penerapan pidana oleh Hakim Pengadilan Tingkat Banding pada putusan Nomor 3/TIPIKOR/2016/PT PDG dan Nomor 9/TIPIKOR/ 2017/PT PDG?

\section{METODE PENELITIAN}

Untuk menjawab permasalahan yang diteliti, spesifikasi penelitian yang penulis lakukan adalah dalam ruang lingkup deskriptif Analitis yaitu suatu penelitian yang menggambarkan dan menguraikan mengenai permasalahan yang akan diteliti. Pendekatan yang digunakan dalam penelitian ini adalah pendekatan yuridis normatif yaitu menguji dan mengkaji data sekunder yang berkaitan dengan Penerapan Unsur-Unsur Pasal 2 dan Pasal 3 Undang-Undang Tipikor dan penerapan pidana oleh Hakim Pengadilan Tingkat Banding pada putusan Nomor 3/TIPIKOR/2016 dan Nomor 9/TIPIKOR/2017serta memahami hukum sebagai seperangkat peraturan atau norma-norma positif di dalam sistem perundang-undangan yang mengatur kehidupan manusia. Data yang digunakan dalam penelitian hukum ini hanya ada sekunder. Dalam memperoleh data sekunder digunakan teknik pengumpulan data melalui penelitian kepustakaan (library research) atau studi dokumen, yaitu dengan cara membaca dan mempelajari bahan-bahan hukum primer, sekunder dan tersier yang ada kaitannya dengan penelitian. Dari data yang penulis peroleh melalui penelitian kepustakaan maka dilakukan analisis data secara kualitatif dengan menafsirkan, kemudian menggambarkan dengan menggunakan kata-kata yang kemudian disajikan secara deskriptif analitis. 


\section{HASIL PENELITIAN DAN PEMBAHASAN}

Pertimbangan Hakim Tingkat Banding Dalam Menerapkan Unsur-unsur Pasal 2 dan Pasal 3 Undang-undang Nomor 31 Tahun 1999 Tentang Pemberantasan Tindak Pidana Korupsi.

Hakim diberi kebebasan untuk menjatuhkan putusan dalam setiap pengadilan perkara tindak pidana, hal tersebut sesuai dengan bunyi Undang-undang Nomor 48 Tahun 2009 tentang Kekuasaan Kehakiman Pasal 1 mengatakan bahwa:

Kekuasaan kehakiman adalah kekuasaan negara yang merdeka untuk menyelenggararan peradilan guna menegakkan hukum dan keadilan berdasarkan Pancasila, demi terselenggaranya Negara Hukum Republik Indonesia.

Dasar pertimbangan hakim dalam menjatuhkan putusan dapat digunakan sebagai bahan analisis tentang orientasi yang dimiliki hakim dalam menjatuhkan putusan juga sangat penting untuk melihat bagaimana putusan yang dijatuhkan itu relevan dengan tujuan pemidanaan, justru tidak akan berdampak negatif terhadap proses penanggulangan kejahatan itu sendiri dan akan membawa manfaat bagi terdakwa. Hakim akan menarik fakta-fakta dalam persidangan yang timbul dan merupakan konklusi komulatif dari keterangan keterangan saksi, keterangan terdakwa dan barang bukti. Pertimbangan hakim dapat dibagi menjadi 2 kategori yakni: Pertimbangan Yuridis dan Pertimbangan Non Yuridis:

\section{Pertimbangan Yuridis}

Pertimbangan yang bersifat yuridis adalah pertimbangan hakim yang didasarkan pada fakta-fakta yang terungkap dipersidangan, oleh undang-undang Pertimbangan Yuridis tersebut telah ditetapkan sebagai hal yang harus dimuat di dalam putusan. Pertimbangan yang bersifat yuridis diantaranya:

a. Dakwaan Jaksa Penuntut Umum

Pada Putusan Nomor 3/TIPIKOR/2016/PT PDG, Majelis Hakim Tingkat Banding sependapat dengan pertimbangan Majelis Hakim Tingkat Pertama dalam putusannya, bahwa perbuatan Terdakwa telah terbukti secara sah dan meyakinkan bersalah melakukan Tindak Pidana Korupsi secara bersama-sama melanggar Pasal 3 Undang-Undang RI Nomor 31 Tahun 1999 yang telah diubah dan ditambah dengan Undang-Undang RI Nomor 20 Tahun 2001 tentang Perubahan atas Undang-Undang RI Nomor 31 Tahun 1999 tentang Pemberantasan Tindak Pidana Korupsi.

Pada Putusan Nomor 9/TIPIKOR/2017/PT PDG, Majelis Hakim Tingkat pertama dalam pertimbangannya menyatakan bahwa para Terdakwa terbukti secara 
sah dan meyakinkan bersalah melakukan Tindak Pidana Korupsi secara bersamasama sebagaimana dakwaan Subsidair. Majelis Hakim Tingkat Banding terlebih dahulu telah memeriksa unsur-unsur tindak pidana yang diadakwakan, ternyata Pasal 2 telah terbukti dan terpenuhi semua unsur-unsur tindak pidana yang didakwakan, sehingga Pasal 3 tidak perlu dipertimbangkan lagi. Majelis Hakim Tingkat Banding tidak sependapat dengan putusan Hakim Tingkat Pertama yang menyatakan perbuatan para Terdakwa telah melanggar Pasal 3, sehingga putusan Pengadilan Tingkat pertama tersebut Nomor 33/Pid.Sus-TPK/2016/PT PDG, haruslah dibatalkan dan Pengadilan Tingkat Banding akan mengadili sendiri.

b. Tuntutan Pidana

Pada Putusan Nomor 3/TIPIKOR/2016/PT PDG, tuntutan Jaksa Penuntut Umum dalam surat tuntutannya pada putusan tingkat banding halaman 17 , alenia 3, diktum 1 dan 3 berbunyi sebagai berikut:

1) Menyatakan terdakwa Drs. H. M. Syamri Adnan, SH. MHI terbukti secara sah dan meyakinkan bersalah melakukan tindak pidana korupsi sebagaimana diatur dan diancam pidana dalam Pasal 2 ayat (1) Jo Pasal 18 ayat (1) huruf a, huruf b, ayat (2) dan ayat (3) Undang-undang Nomor 31 Tahun 1999 yang telah diubah dan ditambah dengan Undang-undang Nomor 20 Tahun 2001 tentang Perubahan atas Undang-Undang Nomor 31 Tahun 1999 tentang Pemberantasan Tindak Pidana Korupsi Jo Pasal 55 ayat (1) ke-1 KUHP.

2) Menjatuhkan Pidana terhadap terdakwa Drs. H. M. Syamri Adnan, SH. MHI dengan pidana penjara selama 6 (enam) Tahun dan 6 (enam) Bulan dengan perintah terdakwa segera untuk ditahan.

Pada putusan Nomor 9/TIPIKOR/2017/PT PDG, tuntutan Jaksa Penuntut

Umum dalam surat tuntutannya pada putusan tingkat banding halaman 58, alenia 3 ,

diktum 1 dan 2, berbunyi sebagai berikut:

a. Menyatakan Terdakwa I Hasrizal Als. Hasrizal Chan Pgl. Chan, Terdakwa II Zulfariadi Pgl. Jun, Terdakwa III Resva Yandri Als. Resfa Yandri dan Terdakwa IV Misdianto Pgl. Edi telah terbukti secara sah dan meyakinkan bersalah melakukan tindak pidana "Turut Serta Melakukan Tindak Pidana Korupsi" sebagaimana yang didakwakan dalam dakwaan Primair melanggar Pasal 2 ayat (1) Jo Pasal 18 ayat (1) huruf a, b, ayat (2), ayat (3) Undang-Undang No. 31 tahun 1999 sebagaimana telah diubah dengan Undang-Undang No. 20 Tahun 2001 tentang Pemberantasan Tindak Pidana Korupsi Jo Pasal 55 ayat (1) ke-1 KUHPidana;

b. Menjatuhkan pidana terhadap:

1) Terdakwa I Hasrizal Als. Hasrizal Chan Pgl. Chan dengan pidana penjara selama 6 (enam) tahun dikurangi selama Terdakwa berada dalam tahanan yang telah dijalani, membayar denda sebesar Rp 200.000.000,00.- (dua ratus juta rupiah) Subsidair 6 (enam) bulan kurungan, membayar Uang Pengganti sebesar Rp124.425.000,00.- (seratus dua puluh empat juta empat ratus dua puluh lima ribu rupiah), jika Terdakwa I Hasrizal Chan tidak membayar uang pengganti paling lama dalam waktu 1 (satu) bulan sesudah putusan pengadilan memperoleh kekuatan hukum tetap, maka harta bendanya dapat disita oleh 
jaksa dan dilelang untuk menutupi uang pengganti tersebut, dalam hal Terdakwa I Hasrizal Chan tidak mempunyai harta benda yang mencukupi untuk membayar uang pengganti maka diganti dengan pidana penjara selama 3 (tiga) tahun;

2) Terdakwa II Zulfariadi Pgl. Jun dengan pidana penjara selama 4 (empat) tahun dan 6 (enam) bulan dikurangi selama Terdakwa berada dalam tahanan yang telah dijalani, membayar denda sebesar Rp 200.000.000,00.- (dua ratus juta rupiah) Subsidair 6 (enam) bulan kurungan, membayar Uang Pengganti sebesar Rp 34.575.000,00.- (tiga puluh empat juta lima ratus tujuh puluh lima ribu rupiah), dikurangi dengan uang yang telah diserahkan Terdakwa II Zulfariadi Pgl. Jun di depan persidangan sebesar Rp 15.000.000,00.- (lima belas juta rupiah) sehingga uang pengganti yang harus dibayar masih kurang sebesar $\mathrm{Rp}$ 19.575.000,00.- (Sembilan belas juta lima ratus tujuh puluh lima ribu rupiah) dan jika Terdakwa II Zulfariadi Pgl. Jun tidak membayar uang pengganti paling lama dalam waktu 1 (satu) bulan sesudah putusan pengadilan memperoleh kekuatan hukum tetap, maka harta bendanya dapat disita oleh jaksa dan dilelang untuk menutupi uang pengganti tersebut, dalam hal Terdakwa II Zulfariadi Pgl. Jun tidak mempunyai harta benda yang mencukupi untuk membayar uang pengganti maka diganti dengan pidana penjara selama 2 (dua) tahun dan 3 (tiga) bulan;

3) Terdakwa III Resva Yandri Als. Resfa Yandri Pgl. Eridengan pidana penjara selama 5 (lima) tahun dan 6 (enam) bulan dikurangi selama Terdakwa berada dalam tahanan yang telah dijalani, membayar denda sebesar Rp 200.000.000,00.- (dua ratus juta rupiah) Subsidair 6 (enam) bulan kurungan, membayar Uang Pengganti sebesar Rp 59.075.000,00.- (lima puluh sembilan juta tujuh puluh lima ribu rupiah), jika Terdakwa III Resva Yandri Pgl. Eri tidak membayar uang pengganti paling lama dalam waktu 1 (satu) bulan sesudah putusan pengadilan memperoleh kekuatan hukum tetap, maka harta bendanya dapat disita oleh jaksa dan dilelang untuk menutupi uang pengganti tersebut, dalam hal Terdakwa III Resva Yandri Pgl. Eri tidak mempunyai harta benda yang mencukupi untuk membayar uang pengganti maka diganti dengan pidana penjara selama 2 (dua) tahun dan 9 (sembilan) bulan;

4) Terdakwa IV Misdianto Pgl. Edidengan pidana penjara selama 5 (lima) tahun dikurangi selama Terdakwa berada dalam tahanan yang telah dijalani, membayar denda sebesar Rp 200.000.000,00.- (dua ratus jutarupiah) Subsidair 6 (enam) bulan kurungan, membayar Uang Pengganti sebesar Rp 37.857.730,00.- (tiga puluh tujuh juta delapan ratus lima puluh tujuh ribu tujuh ratus tiga puluh rupiah), dikurangi dengan uang yang telah diserahkan Terdakwa IV Misdianto Pgl. Edi di depan persidangan sebesar Rp 2.200.000,00.- (dua juta dua ratus ribu rupiah) sehingga uang pengganti yang harus dibayar masih kurang sebesar Rp 35.657.730,00.- (tiga puluh lima juta enam ratus lima puluh tujuh ribu tujuh ratus tiga puluh rupiah) dan jika Terdakwa IV Misdianto Pgl. Edi tidak membayar uang pengganti paling lama dalam waktu 1 (satu) bulan sesudah putusan pengadilan memperoleh kekuatan hukum tetap, maka harta bendanya dapat disita oleh jaksa dan dilelang untuk menutupi uang pengganti tersebut, dalam hal Terdakwa IV Misdianto Pgl. Edi 
tidak mempunyai harta benda yang mencukupi untuk membayar uang pengganti maka diganti dengan pidana penjara selama 2 (dua) tahun dan 6 (enam) bulan;

Pada putusan Nomor 3/TIPIKOR/2016/PT PDG, dan putusan Nomor 9/TIPIKOR/2017/PT PDG, Majelis akan mempertimbangkan dakwaan Penuntut Umum, berdasarkan fakta-fakta yang terungkap dipersidangan sebagaimana yang akan diuraikan di bawah ini, para terdakwa dapat dipersalahkan dan dijatuhi pidana, hal tersebut haruslah dibuktikan terlebih dahulu apakah semua unsur-unsur dalam Dakwaan Penuntut Umum tersebut telah terpenuhi atau tidak.

Bahwa oleh karena Penuntut Umum dalam Surat Tuntutannya telah mempertimbangkan Dakwaan Primair terlebih dahulu, maka Majelis juga akan mempertimbangkan dakwaan Primair terlebih dahulu dengan konsekwensi apabila dakwaan Primair dinyatakan telah terbukti maka Dakwaan Subsidair tidak perlu dibuktikan lagi, akan tetapi apabila Dakwaan Primair dinyatakan tidak terbukti maka Majelis akan mempertimbangkan dakwaan Subsidair.

Pada putusan Nomor 3/TIPIKOR/2016/PT PDG, Penuntut Umum dengan dakwaan Primair menyatakan perbuatan para Terdakwa diatur dan diancam berdasarkan Pasal 2 ayat (1) Undang-undang Tindak Pidana Korupsi Jo Pasal 55 ayat (1) ke-1 Kitab Undang-undang Hukum Pidana. Majelis Hakim Tingkat Banding telah memeriksa unsur-unsur Pasal 2 tersebut, sebagai berikut :

a. Unsur Setiap orang.

b. Unsur Secara melawan hukum.

c. Unsur Memperkaya diri sendiri atau orang lain atau suatu korporasi.

Dari hasil pemeriksaan Ad. 3. Unsur Memperkaya diri sendiri atau orang lain atau suatu korporasi, ditemukan hasil pertimbangan sebagai dibawah ini.

Menimbang bahwa tindakan terdakwa sebagaimana yang diuraikan tersebut di atas menurut hemat Majelis tidaklah menjadikan seseorang bertambah kaya yaitu mempunyai banyak harta apalagi uang tersebut juga dibelikan bahan pakaian untuk karyawan Pengadilan Agama Maninjau, untuk membeli genset, untuk dibelikan tanda pengenal, untuk pembelian Televisi dan Parabola serta untuk membeli Karpet sehingga kepada Terdakwa tidak dapat dipersalahkan telah melakukan perbuatan memperkaya 
diri sendiri atau orang lain atau suatu korporasi dan kepada Terdakwa haruslah dibebaskan dalam dakwaan Primair tersebut.

Bahwa berdasarkan pertimbangan-pertimbangan tersebut di atas Majelis Hakim berpendapat bahwa unsur "memperkaya diri sendiri atau orang lain atau suatu korporasi" tidak terbukti menurut hukum.

Menimbang, bahwa dengan tidak terbuktinya unsur memperkaya diri sendiri atau orang lain atau suatu korporasi yang termaktub dalam Pasal 2 ayat (1) Undangundang Tindak Pidana Korupsi, maka Majelis tidak akan mempertimbangkan unsurunsur selanjutnya dan kepada terdakwa tidak dapat dipersalahkan telah melakukan perbuatan sebagaimana yang didakwakan kepadanya dalam Pasal 2 ayat (1) Undangundang Tindak Pidana Korupsi dan oleh sebab itu kepada Terdakwa haruslah dinyatakan dibebaskan dari Dakwaan Primair dimaksud.

Menimbang, bahwa berdasarkan pertimbangan-pertimbangan di atas, Majelis Hakim berpendapat bahwa keseluruhan unsur-unsur dalam Pasal 3 Undang-undang Tindak Pidana Korupsi Jo Pasal 55 ayat (1) Ke-1 KUHP, telah terpenuhi dan terbukti menurut hukum dalam perbuatan terdakwa.

Menimbang, bahwa Penasihat Hukum Terdakwa dalam memori dan kontra memori bandingnya pada pokoknya menyatakan bahwa Terdakwa tidak terbukti melakukan tindak pidana korupsi sebagaimana yang didakwakan kepadanya, untuk itu mohon untuk dibebaskan dari segala dakwaan dan tuntutan;

Menimbang, bahwa Penuntut Umum dalam memori dan kontra memori bandingnya pada pokoknya menyatakan bahwa dakwaan yang terbukti terhadap perbuatan Terdakwa adalah dakwaan primair, selanjutnya menurut Penuntut Umum, bahwa pidana yang dijatuhkan kepada Terdakwa masih jauh dari rasa keadilan masyarakat dan uang pengganti yang harus dikembalikan oleh Terdakwa adalah sejumlah Rp92.105.895,00 (sembilan puluh dua juta seratus lima ribu delapan ratus sembilan puluh lima rupiah);

Menimbang, bahwa setelah Pengadilan Tindak Pidana Korupsi pada Pengadilan Tinggi Padang membaca dan meneliti berkas perkara dengan seksama, mencermati putusan Pengadilan Tindak Pidana Korupsi pada Pengadilan Negeri Padang Nomor 39/Pid.Sus/TPK/2015/PN.PDG, tanggal 15 Maret 2016, memperhatikan memori 
banding dari Penasihat Hukum Terdakwa Memori Banding dari Penuntut Umum, Kontra memori banding dari Penasihat Hukum Terdakwa dan kontra memori banding dari Penuntut Umum tersebut, Majelis Hakim Pengadilan Tinggi sependapat dengan pertimbangan hakim Pengadilan Tingkat Pertama dalam putusannya, bahwa perbuatan Terdakwa telah terbukti dengan sah dan meyakinkan bersalah melakukan Tindak Pidana Korupsi secara bersama-sama melanggar Pasal 3 jo Pasal 18 ayat (1) huruf a dan b, ayat (2) dan ayat (3) Undang Undang Nomor 31 Tahun 1999 tentang Pemberantasan Tindak Pidana Korupsi sebagaimana telah diubah dan ditambah dengan Undang-Undang Nomor 20 Tahun 2001 jo Pasal 55 ayat (1) ke-1 KUHP sebagaimana dakwaan subsidair lantaran Terdakwa telah menerima sebagian uang kelebihan proyek pembelian tanah untuk kepentingan pembangunan gedung Pengadilan Agama Maninjau dan pertimbangan hakim tingkat pertama tersebut diambil alih dan dijadikan sebagai pertimbangan Pengadilan Tinggi sendiri dalam memutus perkara ini;

Menimbang, bahwa berdasarkan pertimbangan tersebut putusan pengadilan tingkat pertama dapat dikuatkan dengan perbaikan yang menyangkut lamanya pidana yang dijatuhkan kepada terdakwa dan redaksi mengenai pidana uang pengganti;

Pada putusan Nomor 9/TIPIKOR/2017/PT PDG, dalam putusan Pengadilan Tingkat Pertama menyatakan bahwa para Terdakwa terbukti secara sah dan meyakinkan bersalah melakukan Tindak Pidana Korupsi secara bersama-sama sebagaimana dalam dakwaan Subsidair dan Hakim Tingkat Banding berdasarkan semua pertimbangannya yang menyatakan semua unsur yang terkandung dalam Pasal 2 Undang-undang Nomor 31 Tahun 1999 tentang Pemberantasan Tindak Pidana Korupsi terbukti dalam perbuatan Terdakwa, putusan Pengadilan Tindak Pidana Korupsi pada Pengadilan Negeri Padang Nomor 33/Pid.Sus-TPK/2016/PN.Pdg.,tanggal 27 Januari 2017 yang menyatakan perbuatan Terdakwa telah terbukti secara sah dan meyakinkan bersalah melanggar dakwaan subsidair sebagaimana diatur Pasal 3 jo Pasal 18 ayat (1) huruf $b$ ayat (2) dan ayat (3) Undang-Undang No.31 Tahun 1999 tentang Pemberantasan Tindak Pidana Korupsi sebagaimana telah dirubah dengan UndangUndang Nomor 20 Tahun 2001 haruslah dibatalkan dan selanjutnya Pengadilan Tingkat banding mengadili sendiri perkara ini sebagaimana tercantum dalam amar putusan ini ; 


\section{Pertimbangan Non Yuridis}

Pada putusan Nomor 3/TIPIKOR/2016 pertimbangan non yuridis yang bersifat sosiologis masih ada hal-hal yang memberatkan, KUHP hanya mengatur hal-hal yang dijadikan alasan memberatkan pidana tersebut yaitu:

a. Jabatan

Pemberatan dalam jabatan ditentukan dalam Pasal 52 KUHP yang berbunyi "bilamana seseorang pejabat karena melakukan tindak pidana, melanggar suatu kewajiban khusus dari jabatannya atau pada waktu melakukan tindak pidana memakai kekuasaan, kesempatan atau sarana yang diberikan kepadannya karena jabatannya dapat ditambah sepertiganya.

Hakim Tingkat Banding sependapat dalam pertimbangan Hakim Tingkat Pertama, sedangkan pada diktum angka 4 amar putusan tersebut hakim tingkat pertama dalam penjatuhan pidana menurut tuntutan Jaksa penuntut Umum tersebut masih jauh dari rasa keadilan masyarakat dan menurut Majelis Hakim Tingkat Banding memberikan pertimbangan Non Yuridis yang bersifat sosiologis dan sosial justice pada putusan tingkat banding halaman 32 alenia 3 bahwa pidana penjara tersebut perlu diperberat karena masih ada hal-hal yang belum dipertimbangkan oleh Pengadilan Tingkat Pertama terhadap Terdakwa Drs.. H. M. Syamri Adnan, S.H., MH.I sebagai berikut:

1) Bahwa Terdakwa adalah berkedudukan sebagai seorang hakim.

2) Bahwa Terdakwa adalah sebagai seorang Ketua Pengadilan Agama yang juga berfungsi sebagai pengawas kegiatan terutama yang berkaitan dengan penggunaan anggaran pada Pengadilan Agama Maninjau yang dipimpin oleh Terdakwa.

3) Bahwa Terdakwa sebagai seorang hakim dan Ketua Pengadilan Agama ternyata tidak menjaga nama baik dan kehormatan korp hakim dan Pengadilan.

Dengan demikian putusan Pengadilan Tingkat Banding berbunyi sebagai berikut:

a. Menyatakan Terdakwa Drs. H. M. Syamri Adnan, S.H., MH.I telah terbukti secara sah dan meyakinkan bersalah melakukan "Tindak Pidana Korupsi secara bersamasama" sebagaimana Dakwaan Subsidair.

b. Menjatuhkan Pidana kepada Terdakwa Drs. H. M. Syamri Adnan, S.H, MH.I oleh karena itu dengan pidana penjara selama 3 (tiga) tahun dan denda sebesar Rp. 50.000.000,00 (lima puluh juta) rupiah dengan ketentuan apabila denda tersebut tidak dibayar diganti dengan pidana kurungan selama 2 (dua) bulan. 
b. Pada Putusan Nomor 9/TIPIKOR/2017/PT PDG

Menimbang, bahwa sebelum Majelis Hakim menjatuhkan pidana terhadap Para Terdakwa, terlebih dahulu akan dipertimbangkan hal-hal yang memberatkan dan yang meringankan hukuman Para Terdakwa, yakni sebagai berikut:

\section{Hal-hal yang memberatkan:}

Perbuatan Para Terdakwa tidak mendukung program pemerintah dalam upaya pemberantasan korupsi;

\section{Hal-hal yang meringankan:}

1. Para Terdakwa bersikap sopan dipersidangan;

2. Terdakwa II dan Terdakwa IV telah mengembalikan sebagian kerugian keuangan negara

3. Terdakwa adalah sebagai pencari nafkah untuk keluarga, dan mempunyai tanggungan isteri dan anak-anak;

4. Terdakwa belum pernah dijatuhi pidana;

Majelis Hakim Tingkat Banding berpendapat bahwa hukuman yang dijatuhkan atas diri Terdakwa sudah memenuhi rasa keadilan;

Menimbang, bahwa Majelis Hakim Tingkat Pertama dinilai telah tepat dan benar mempertimbangkan hal-hal yang memberatkan dan meringankan hukuman Terdakwa, namun menurut hemat Pengadilan Tingkat Banding yang lebih memperberat hukuman para Terdakwa adalah perbuatan Terdakwa menghambat tercapainya kesejahteraan masyarakat melalui program Penyelamatan sapi/kerbau betina produktif;

Menimbang, bahwa dengan mempertimbangkan hal-hal tersebut di atas menurut Majelis Hakim Tingkat Banding, pidana yang dijatuhkan terhadap para Terdakwa sebagaimana tersebut dalam amar putusan ini sudah setimpal dengan kadar kesalahan para Terdakwa dan dirasa telah adil setelah memperhatikan social justice, moral justice dan legal justice;

\section{Penerapan pidana oleh Hakim Pengadilan Tingkat Banding}

Putusan Nomor 3/TIPIKOR/2016/PT PDG, berdasarkan dakwaan Penuntut Umum dan unsur-unsur tindak pidana yang telah terpenuhi terbukti bahwa perbuatan Terdakwa diatur dan diancam Pasal 3 Undang-undang Nomor 31 Tahun 1999 Tentang Pemberantasan Tindak Pidana Korupsi sebagaimana telah diubah dan ditambah dengan Undang-undang Nomor 20 Tahun 2001, maka penerapan pidana oleh Hakim Tingkat banding memperhatikan Pasal 3 tersebut, yang mana termuat dalam amar putusan Nomor 3/TIPIKOR/2016/PT PDG, point 3 dan 4:

1. Menyatakan Terdakwa Drs. H. M. Syamri Adnan, SH, MH.I telah terbukti secara sah dan meyakinkan bersalah melakukan "Tindak Pidana Korupsi secara bersamasama” sebagaimana Dakwaan Subsidair. 
2. Menjatuhkan Pidana kepada Terdakwa Drs. H. M. Syamri Adnan, SH, MH.I oleh karena itu dengan pidana penjara selama 3 (tiga) tahun dan denda sebesar Rp. 50.000.000,00 (lima puluh juta) rupiah dengan ketentuan apabila denda tersebut tidak dibayar diganti dengan pidana kurungan selama 2 (dua) bulan.

Menimbang, bahwa berdasarkan pertimbangan tersebut di atas, maka putusan Pengadilan Tindak Pidana Korupsi pada Pengadilan Negeri Padang Nomor 39/Pid.Sus TPK/2015/PN.Pdg, tanggal 15 Maret 2016 harus diperbaiki sekedar mengenai lamanya pidana yang dijatuhkan kepada Terdakwa pada diktum ke-4 dan redaksi amar mengenai uang pengganti pada diktum ke-5, karena menurut hemat Pengadilan Tinggi pidana yang dijatuhkan oleh Pengadilan Tingkat Pertama belum setimpal dengan kesalahan yang dilakukan oleh Terdakwa, dan adalah adil apabila Terdakwa dipidana seperti tersebut dalam amar di bawah ini, sedangkan putusan selebihnya dapat dikuatkan.

Putusan Nomor 9/TIPIKOR/2017/PT PDG, berdasarkan dakwaan Penuntut Umum yang berbentuk subsidairitas, pada putusan Pengadilan Tingkat Pertama para Terdakwa terbukti secara sah dan meyakinkan bersalah melakukan Tindak Pidana Korupsi secara bersama-sama sebagaimana dalam dakwaan Subsidair, setelah Majelis Hakim Tingkat Banding memeriksa dan mempelajari berkas perkara tersebut, ternyata dakwaan Primair serta unsur-unsur tindak pidananya terbukti atas perbuatan para Terdakwa, Majelis Hakim Tingkat Pertama dinilai telah tepat dan benar mempertimbangkan hal-hal yang memberatkan dan meringankan, namun menurut Majelis Hakim Tingkat Banding yang lebih memperberat hukuman para Terdakwa adalah perbuatan para Terdakwa menghambat tercapainya kesejahteraan masyarakat melalui program Penyelamatan Sapi/Kerbau betina produktif.

Bahwa berdasarkan pertimbangan tersebut ternyata semua unsur yang terkandung dalam Pasal 2 ayat (1) Undang-Undang Nomor 31 tahun 1999 tentang Pemberantasan Tindak Pidana Korupsi sebagaimana telah diubah dan ditambah dengan undang-undang Nomor 20 Tahun 2001 telah terbukti secara sah dan meyakinkan bersalah melanggar Pasal 2 tersebut dalam Dakwaan Primair, selanjutnya putusan Pengadilan Tingkat Pertama haruslah dibatalkan dan Pengadilan Tinggi mengadili sendiri dan pidana yang diterapkan oleh Hakim Tinggi Banding dengan memperhatikan Pasal 2 Undang-undang Nomor 31 Tahun 1999 Tentang Pemberantasan Tindak Pidana Korupsi sebagaimana telah diubah dan ditambah dengan Undang-undang Nomor 20 Tahun 2001, sebagaimana dalam amar 
putusan A quo point 2 penjatuhan pidana terhadap terdakwa II dan Terdakwa IV masingmasing berubah menjadi selama 4 (empat) tahun.

\section{PENUTUP}

\section{Kesimpulan}

1. Pertimbangan Hakim Tingkat Banding Dalam Menerapkan Unsur-unsur Pasal 2 dan Pasal 3 Undang-undang Nomor 31 Tahun 1999 Tentang Pemberantasan Tindak Pidana Korupsi

Pada Putusan Nomor 3/TIPIKOR/2016/PT PDG, pertimbangan hukum Hakim Tingkat Pertama dalam putusannya dapat disetujui dan dikuatkan oleh Hakim Tingkat Banding, kecuali dalam hal penjatuhan pidana kepada Terdakwa, menurut Hakim Tingkat Banding pidana yang dijatuhkan tersebut perlu diperberat dan masih ada hal-hal yang memberatkan bagi Terdakwa yang belum dipertimbangkan oleh Hakim Tingkat Pertama tersebut.

Pertimbangan Hakim pada Putusan Nomor 9/TIPIKOR/ 2017/PT PDG, para Terdakwa telah melakukan Penyimpangan Penggunaan Dana Bantuan Sosial Penyelamatan Sapi/Kerbau Betina Produktif, Hakim Tingkat pertama meyatakan perbuatan para Terdakwa terbukti dan bersalah sebagaimana diatur dan diancam pidana dalam dakwaan Primair penuntut Umum Pasal 3 Undang-undang Nomor 31 Tahun 1999 Tentang Pemberantasan Tindak Pidana Korupsi. Majelis Hakim Tingkat Banding dengan segala pertimbangannya menyatakan bahwa Pasal 2 dengan unsur-unsur tindak pidana yang dilakukan para Terdakwa telah terpenuhi dan terbukti, maka unsur-unsur Pasal 3 tak perlu dipertimbangkan lagi. Maka putusan Pengadilan Negeri Padang Nomor 33/Pid.Sus-TPK/ 2016/PN Pdg, haruslah dibatalkan dan Pengadilan Tinggi mengadili sendiri.

2. Penerapan pidana oleh Hakim Pengadilan Tingkat Banding

Pada putusan Nomor 3/TIPIKOR/2016/PT PDG, adalah memperbaiki putusan Pengadilan Tingkat Pertama yang menjatuhkan pidana penjara selama 2 (dua) tahun dan 6 (enam) bulan dan perbaikan pidana yang dijatuhkan Pengadilan Tingkat Banding adalah penjatuhan pidana penjara selama 3 (tiga) tahun dan denda 
sebesar Rp50.000.000,00 (lima puluh juta rupiah) dengan ketentuan apabila denda tersebut tidak dibayar diganti dengan pidana kurungan selama 2 (dua) bulan.

Penerapan pidana oleh Hakim Pengadilan Tingkat Banding pada putusan Nomor 9/TIPIKOR/2017/PT PDG, berbeda dengan putusan Pengadilan Tingkat Pertama yang menjatuhkan pidana kepada terdakwa II dan IV masing-masing 3 (tiga) tahun dan 6 (enam) bulan serta denda Rp. 50.000.000,00 (lima puluh juta rupiah), Subsidair 2 (dua) bulan kurungan, sedangkan pada putusan tingkat banding menjatuhkan pidana selama 4 tahun dan denda Rp. 200.000.000,00 (dua ratus juta rupiah) subsidair 2 (dua) bulan kurungan.

\section{Saran-saran}

Terhadap pelaku tindak pidana korupsi Indonesia khususnya sudah semestinya diberikan hukuman yang tinggi dan pidana yang dijatuhi lebih berat sehingga akan menimbulkan efek jera bagi para pelaku dan pembelajaran bagi masyarakat jangan ikut melakukan tindak pidana korupsi yang akan diberikan ganjaran yang setimpal atas perbuatannya. Bagi masyarakat dianjurkan supaya jangan melakukan tindak pidana korupsi dan jangan ikut-ikutan dalam melakukan korupsi, agar kita semua ikut bersama-sama memerangi korupsi dan membenci koruptor karena tindakan dan perbutannya merugikan keuangan Negara atau perekonomian Negara.

\section{DAFTAR PUSTAKA}

\section{Buku Teks:}

Alan Coffey, An Introduction to The Criminal Justice System and Process, Prentice-Hall Inc, New Jersey, 1974.

Adami Chazawi, Pelajaran Hukum Pidana I, PT RajaGrafindo Persada, Jakarta, 2014.

Andi Hamzah, Asas-Asas Hukum Pidana, PT Rineka Cipta, Jakarta, Cetakan IV, 2010.

Baharuddin Lopa \& Moh. Yamin, Masalah Korupsi dan Pemecahannya, Kipas Putih Aksara, Jakarta, 1977.

Barda Nawawi Arief, Masalah Penegakan Hukum dan Kebijakan Hukum Pidana Dalam Penanggulangan Kejahatan, Kencana Media Group, Jakarta, 2007.

Chairul Huda, Dari Tiada Hari Tanpa Kesalahan Menuju Kepada Tiada Pertanggungjawaban Pidana Tanpa Kesalahan Tinjuan Krisis TerhadapTeori Pemisahan Tindak Pidana dan PertanggungJawaban Pidana, Kencana, Jakarta, 2006. 
Darwan Prints, Pemberantasan Tindak Pidana Korupsi, PT Citra Aditya Bakti, Bandung, 2002.

Darji Damodiharjo dan Sidharta, Pokok-Pokok Filsafat Hukum (Apa dan Bagaimana Filsafat Hukum Indonesia), PT. Gramedia Pustaka Utama, Jakarta, 2006.

Djohanjah, Akses Pada Keadilan, Makalah pada Pelatihan HAM bagi Jejaring Komisi Yudisial, Bandung, 3 Juli 2010.

Elwi Danil, Korupsi Tindak Pidana dan Pemberantasannya, PT Raja Grafindo Persada, Jakarta 2011.

E.Y. Kenter, S.R. Sianturi, Asas-Asas Hukum Pidana Indonesia dan Penerapannya, Storia Grafika, Jakarta, 2012.

George P. Fletcher, Rethingking Criminal Law, Oxfor University Pres, 2000, dikutip dari Chairul Huda.

H. Zamhari Abidin, Pengertian Dan Azas-Azas Hukum Pidana Dalam Schema (Bagan) Dan Sinopsis (Catatan Singkat), Galia Indonesia, Jakarta, 1986

Hamzah Hatrik, Azas Pertanggungjawaban Koporasi Dalam Hukum Pidana, $\quad$ Cet.I, Raja Grafindo Prasaja, Jakarta, 1996.

Indrianto Seno Adji \& Juan Felix Tambulon, Perkara H.M Soeharto, Multi Mediametri, 2001.

J.C Smith dan Brian Hogan, Criminal Law, Butterwords, London, 1969, Lihat Chairul Huda Dari Tiada Pidana Tanpa Kesalahan Menuju Kepada Pertanggungjawaban Pidana Tanpa Kesalahan Tinjau Krisis Terhadap Teori Pemisahan Tindak Pidana dan Pertanggungjawaban Pidana, Kencana, Jakarta, 2006.

P.A.F Lamintang, Dasar-dasar Hukum Pidana Indonesia, Sinar Baru, $\quad$ Bandung, 1984.

Juniver Girsang, Abuse or Power, Penyalahgunaan Kekuasaan Aparat Penegak Hukum Dalam Penanganan Tindak Pidana Korupsi, J.G Publishing, 2012.

Mauro Cappeletti, Toward Equal Justice; A Comparative Study of Legal Aid $\quad$ Modern Society Dobbs Ferry, New York, 1975.

Muladi, Kapita Selekta Sistem Peradilan Pidana, Badan Penerbit Universitas, Diponegoro, Semarang, 1995.

Moh. Faisal Salam, Pemberantasan Tindak Pidana Korupsi, Cet.I, Pustaka, Bandung, 2004.

Muladi dan Syaiful Bahri, Pidana Denda Dan Korupsi, Total Media, $\quad$ Yogyakarta, 2009.

Marwan Mas, Pemberantasan Tindak Pidana Korupsi, Ghalia Indonesia, 2014.

Nyoman Serikat Putra Jaya, Tinda Pidana Korupsi, Kolusi dan Nepotisme di Indonesia, Universitas Diponegoro, Semarang, 2000.

Prayitno Iman Santoso, Pertanggungjawaban Pidana Korupsi, Alumni, 2015. 
Ruslan Saleh, Perbuatan Pidana Dan Pertanggungjawaban Pidana, Dua Pengertian Dasar Dalam Hukum Pidana, Aksara Baru, Jakarta, 1981.

R. Wiyono, Pembahasan Undang-undang Pemberantasan Tindak Pidana Korupsi, Ed.II, Sinar Grafika, Jakarta, 2008.

R. Soenarto Soerodibroto, KUHP, PT.Raja Grafindo Persada, Jakarta, 2003.

Romli Atmasasmita, Sistem Peradilan Pidana, Perspektif Eksistensialisme dan ablisionisme, CV.Bina Cipta, Bandung, 1996.

Soejono Soekanto, Faktor-Faktor Yang Mempengaruhi Penegakan Hukum, Raja Grafindo Persada, Jakarta, 1983.

\section{Peraturan Undang-Undang :}

Undang-undang Nomor 31 Tahun 1999 Tentang Pemberantasan Tindak Pidana Korupsi sebagaimana telah diubah dan ditambah dengan Undang-undang Nomor 20 Tahun 2001 terbukti perbuatan Terdakwa

Undang-undang Nomor 48 Tahun 2009 tentang Kekuasaan Kehakiman 